\title{
STRATEGI PEMASARAN UNTUK MENINGKATKAN KEUNGGULAN KOMPETITIF PADA PT. TELKOM PONTIANAK
}

\author{
MOCHAMMAD FAISAL FADLI \\ faisal.sw88@gmail.com \\ Akademi Sekretari Manajemen Indonesia Pontianak
}

\begin{abstract}
This study is to determine how marketing strategies to increase competitive advantage at PT. Telkom Pontianak. The number of respondents was 18 respondents. The instrument used for data collection was in the form of a Likert scale questionnaire This study uses a descriptive method in the form of a questionnaire, which is an information collection technique that allows the analysis to study attitudes, behaviors, and characteristics, some of the main people in the organization who can be influenced by the proposed system or by the existing system. Based on data analysis, agree that price, product, promotion and distribution are factors that affect the level of marketing strategy. Constraints faced by PT. Telkom Pontianak In Improving Marketing Strategy, namely Collaboration, Target Achievement, and Environmental conditions. Efforts Made By PT. Telkom Pontianak In Facing Marketing Constraints is Recognizing Customers, Promoting, and Choose a strategic location
\end{abstract}

Key word: Marketing Strategy

\begin{abstract}
ABSTRAK
Penelitian ini bertujuan untuk mengetahui bagaimana strategi pemasaran untuk meningkatkan keunggulan bersaing pada PT. Telkom Pontianak. Jumlah responden sebanyak 18 responden. Instrumen yang digunakan untuk pengumpulan data berupa angket skala likert. Penelitian ini menggunakan metode deskriptif berupa kuesioner yaitu suatu teknik pengumpulan informasi yang memungkinkan analisis untuk mempelajari sikap, perilaku, dan karakteristik, beberapa orang utama dalam organisasi yang dapat dipengaruhi oleh sistem yang diusulkan atau oleh sistem yang ada. Berdasarkan analisis data disepakati bahwa harga, produk, promosi dan distribusi merupakan faktor-faktor yang mempengaruhi tingkat strategi pemasaran. Kendala yang dihadapi PT. Telkom Pontianak Dalam Meningkatkan Strategi Pemasaran yaitu Kolaborasi, Pencapaian Target, dan Kondisi Lingkungan. Upaya Yang Dilakukan PT. Telkom Pontianak Dalam Menghadapi Kendala Pemasaran adalah Mengenali Pelanggan, Mempromosikan, dan Memilih Lokasi yang Strategis
\end{abstract}

Kata Kunci: Strategi Pemasaran 
PENDAHULUAN

Industri mobile telecommunication (telekomunikasi bergerak) di Indonesia tumbuh dengan pesat dari berbasis regulasi menjadi berbasis pasar. Sektor telekomunikasi pada awalnya dimonopoli oleh pemerintah dalam memberi layanan telekomunikasi di Indonesia. Proses reformasi telekomunikasi bermaksud untuk meningkatkan persaingan, menghapus monopoli, meningkatkan transparansi dan kepastian terhadap kerangka regulasi, menciptakan peluang bagi aliansi strategis dengan mitra asing dan memfasilitas masuknya pemain baru dalam industri telekomunikasi. Undang-undang Telekomunikasi (UU No.36/1999) memfasilitasi masuknya pemain sehingga persaingan dalam industri telekomunikasi semakin tinggi. Permenkominfo No.1 tahun 2010 menjadi dasar liberalisasi telekomunikasi di Indonesia karena memperkenankankan orang asing untuk ikut terlibat dalam industri telekomunikasi di Indonesia. Hal ini menyebabkan penyelenggara terbesar layanan telekomunikasi dan jaringan di Indonesia yaitu Telkom dan anak perusahaannya yaitu Telkomsel melakukan perubahan strategi bisnis.

Layanan telekomunikasi yang memiliki persaingan tinggi adalah seluler. Pangsa pasar dari industri seluler tertinggi pada tahun 2012 adalah Telkomsel dengan prosentase 44,55\%, Indosat 20,81\%, XL 16,29\%, HCPT 8,93\%, Axis 5,61\%, Smartfren 3,80\% dan Ceria 0,02\% (Green Power for Mobile, 2012). Pada tahun 2013, pangsa pasar tertinggi juga masih diduduki oleh Telkomsel dengan prosentase di atas $40 \%$ dan melayani 125 juta pelanggan (The Jakarta Post, 13 Juni 2013). Telkomsel merupakan anak perusahaan PT Telkom yang mengoperasikan layanan pada jaringan GSM/DCS, GPRS, EDGE, 3,5 G, serta 5 G. Operator telepon seluler GSM bersaing terutama atas dasar harga, merek, jangkauan jaringan, kualitas jaringan, distribusi, teknologi, layanan bernilai tambah dan kualitas layanan (Laporan Tahunan PT Tekom Indonesia, 2012). Strategi bisnis Telkomsel sebagai perusahaan seluler yang memiliki pangsa pasar tertinggi di Indonesia mengalami pergeseran dari perioda ke perioda sesuai dengan perkembangan lingkungan baik lingkungan bisnis maupun regulasi pemerintah.

Strategi adalah opsi yang dipilih organisasi tentang apa yang akan dilakukan dan apa yang tidak akan dilakukan, pada level strategik memilih strategi artinya menyediakan pilihan paling baik antara lingkungan dan sumber daya internal untuk mencapai tujuan organisasi (Atkinson dkk., 2012). Perencanaan strategik (strategic planning) merupakan bagian dari managemen strategik yang berorientasi untuk mengantisipasi kondisi eksternal. Tipologi strategi menurut Porter (1980) terdiri dari low-cost strategy and diferensiasi. Riset empiris oleh Govindarajan dan Fisher (1990) menunjukkan pengendalian output dan pengalokasian sumber daya yang tinggi berkaitan dengan efektivitas yang lebih tinggi atas low-cost strategy, serta pengendalian 
perilaku dan pengalokasian sumber daya yang tinggi berhubungan dengan efektivitas yang lebih tinggi untuk strategi diferensiasi. Porter juga menyinggung cakupan strategi perusahaan sebagai rencana managemen yang ditujukan untuk menumbuhkan bisnis, menarik dan memuasi pelanggan, memenangi persaingan, menjalankan operasi perusahaan, dan meningkatkan kinerja keuangan perusahaan.

Porter (2008) memperkenalkan lima keunggulan kompetitif (five competitive forces) dalam menformulasikan dan mengimplementasikan strategi jangka panjang. Porter (1985) menyatakan bahwa alat untuk mendiagnosa keunggulan kompetitif dan menemukan cara untuk meningkatkannya adalah melakukan analisis rantai nilai (value chain analysis). Lima keunggulan kompetitif menurut Porter adalah pemasok, pendatang baru, pembeli, produk substitusi dan kompetisi dalam industri. Di luar lingkungan kompetisi, perusahaan menghadapi perubahan-perubahan yang ada pada lingkungan makro. Perubahan teknologi yang revolusioner, misalnya, akan mempengaruhi posisi industri di mana perusahaan berada. Peraturan perundangundangan juga merupakan variabel penentu stabilitas industri.Demikian pula halnya dengan dinamika yang terjadi pada lapangan ekonomi, sosial, budaya, keamanan, dan demografi.

Kondisi yang terjadi pada lingkungan bisnis Telkom sebagai pemegang pangsa pasar tertinggi produk seluler di Indonesia dari tahun ke tahun juga mengalami pergeseran. Hal ini menarik untuk ditelaah lebih mendalam untuk mengetahui bagaimana transformasi pemasaran strategik Telkom sampai dengan perioda terkini, Apakah strategi Telkom yang lama masih efektif dengan kondisi saat ini yang lebih kompetitif.

\section{Permasalaham dan Tujuan}

Untuk dapat melihat dan menilai bagaimana penerapan strategi pemasaran dalam meningkatkan keunggulan kompetitif pada PT. Telkom. Tujuan dari penelitian ini adalah mengetahui penerapan strategi pemasaran untuk meningkatkan keunggulan kompetitif pada PT. Telkom.

\section{TINJAUAN TEORITIS}

\section{Pengertian Pemasaran}

Menurut American Marketing Association 2007 pemasaran adalah aktivitas, serangkaian institusi dan proses menciptakan, mengkomunikasikan, menyampaikan, dan mempertukarkan tawaran yang bernilai bagi pelanggan, klien, mitra, dan masyarakat umum (Tjiptono dan Chandra, 2012, p.3) 


\section{Pengertian Strategi Pemasaran}

Strategi pemasaran menurut Kotler and Amstrong $(2012,72)$ adalah logika pemasaran pemasaran,

Telkom dimana perusahaan berharap dapat menciptakan nilai bagi customer dan dapat mencapai hubungan yang menguntungkan dengan pelanggan. Strategi pemasaran adalah rencana yang menjabarkan ekspektasi perusahaan akan dampak dari berbagai aktivitas atau program pemasaran terhadap permintaan produk atau lini produknya di pasar sasaran tertentu.

\section{Pengertian Strategi Produk}

Menurut basu swastha (2016:211) harga adalah sejumlah uang (ditambah beberapa barang kalau mungkin) yang dibutuhkan untuk mendapatkan sejumlah kombinasi dari barang beserta pelayanannya. Sedangkan Kotler, mendefinisikan produk adalah segala sesuatu yang ditawarkan kepada pasar untuk diperhatikan, dibeli, dipergunakan, dan dikonsumsi sehingga mungkin memuaskan keinginan dan kebutuhan (2002:11). Jasa yang dipasarkan oleh PT. Telkom adalah jasa layanan telekomunikasi dan jaringan.

\section{Pengertian Strategi Harga}

Menurut Kotler dan keller (2012:67) menyatakan harga adalah cara untuk mengukur suatu barang atau jasa yang dinilai dengan uang guna memperoleh barang atau jasa tersebut. Pada dasarnya harga merupakan persoalan penting yang dapat mempengaruhi tingkat penjualan dan tingkat keuntungan yang akan dicapai oleh suatu perusahaan.

\section{Pengertian Strategi Promosi}

Menurut Kotler (2002:74), Promosi sebagai kreativitas mengkomunikasikan keunggulan produk serta membujuk pelanggan sasaran untuk membelinya. Promosi merupakan salah satu strategi pemasaran yang sangat penting dilakukan oleh perusahaan dalam memasarkan sebuah produk atau jasa yang dimilikinya. Strategi promosi yang dilakukan sejalan dengan perencanaan pemasaran serta diarahkan dan dikendalikan dengan baik dengan harapan akan mempengaruhi dalam meningkatkan penjualan.

\section{METODE PENELITIAN}

\section{Desain Penelitian}

Dalam setiap penelitian tentunya dibutuhkan suatu arahan yang digunakan untuk mengolah setiap variabel masukkan yang ada untuk diolah menjadi hasil penelitian yang akan menjawab permasalahan penelitian. Pada penelitian ini, metode penelitian yang digunakan 
adalah metode penelitian deskriptif. Metode penelitian deskriptif adalah prosedur pemecahan masalah yang diselidiki dengan menggambarkan atau menuliskan keadaan subjek atau objek penelitian, pada masa saat sekarang berdasarkan faktor-faktor yang tampak atau sebagaimana mestinya (Nawawi, 2015; 63).

Metode dilakukan dengan ditunjang oleh beberapa kegiatan seperti kuesioner, wawancara, dan survei langsung. Data primer diperoleh dari hasil wawancara dengan pimpinan PT. Telkom, serta menggunakan media kuesioner yang didistribusikan langsung kepada setiap pegawai PT. Telkom. Data sekunder berasal dari penelitian mengenai berkas yang telah ada yang berkaitan atau mempunyai hubungan dengan penelitian. Teori yang digunakan yaitu strategi pemasaran yang terdiri dari strategi harga, strategi produk, strategi promosi, dan strategi distribusi.

\section{Populasi}

Menurut Sudjana (2001:3) populasi adalah keseluruhan objek penelitian yang mempunyai karakteristik tertentu yang menjadi sumber data penelitian. Populasi dalam penelitian ini adalah seluruh karyawan PT Telkom Pontianak yang berjumlah 60 orang.

\section{Sampel}

Menurut Arikunto (2009:11) bahwa "Sampel adalah bagian dari populasi sebagian atau wakil populasi yang diteliti”. Sedangkan menurut Sugiyono (2008:118) menjelaskan bahwa "Sampel memiliki arti suatu bagian dari keseluruhan serta karakteristik yang dimiliki oleh sebuah populasi". Dari pendapat kedua ahli diatas dapat disimpulkan bahwa "Sampel adalah bagian dari populasi yang dapat atau akan diteliti. Dalam penelitian ini penulis mengambil sampel sebanyak 18 responden yang bekerja sebagai Staff pada PT Telkom Pontianak.

\section{Alat Analisis Data}

Penelitian ini merupakan penelitian deskriptif, dengan menggunakan analisa deskriptif atau statistik deskriptif. Menurut Sugiyono (2003:21) bahwa statistik deskriptif adalah "statistik yang berfungsi untuk mendeskripsikan atau memberi gambaran terhadap objek yang diteliti melalui data sampel atau populasi sebagaimana adanya, tanpa melakukan analisis dan membuat kesimpulan yang berlaku untuk umum".

Data dari angket penelitian ini merupakan data kuantitatif yang akan dianalisis secara deskriptif persentase dengan langkah-langkah menurut Ridwan (2004:71-95) sebagai berikut :

a. Menghitung nilai responden dan masing-masing aspek atau sub variabel.

b. Merekap nilai 
c. Menghitung nilai rata-rata

d. Menghitung persentase dengan rumus:

$$
\mathrm{DP}=\frac{\mathrm{n}}{\mathrm{N}} \times 100 \%
$$

Keterangan

$$
\begin{array}{ll}
\mathrm{DP} & =\text { Deskriptif Persentase (\%) } \\
\mathrm{n} & =\text { Skor Empirit (skor yang diperoleh) } \\
\mathrm{N} & =\text { Skor maksimal item pertanyaan }
\end{array}
$$

Untuk menentukan jenis deskriptif persentase yang diperoleh masing-masing indikator dalam variabel, dan menghitung deskriptif persentase kemudian ditafsirkan kedalam kalimat. Metode ini merupakan penskalaan tanggapan yang menggunakan respon sebagai dasar penentuan nilai skalanya. Jumlah alternatif respon yang ada dalam skala likert ada 5 jenis yaitu sebagai berikut :

Tabel 1

Alternatif jawaban dengan Skala Likert

\begin{tabular}{|c|c|}
\hline Jawaban & Skala Likert \\
\hline Sangat Setuju & 5 \\
Setuju & 4 \\
Cukup Setuju & 3 \\
Kurang Setuju & 2 \\
Tidak Setuju & 1 \\
\hline
\end{tabular}

Untuk mengurangi kecenderungan responden menjawab pilihan ragu-ragu, maka pada penelitian ini pilihan jawaban ragu-ragu sengaja tidak diberikan sebagai alternatif jawaban bagi responden seperti yang ditunjukkan pada tabel dibawah ini :

Tabel 2

Alternatif jawaban dengan Skala Likert

\begin{tabular}{|c|c|}
\hline Jawaban & Skala Likert \\
\hline Sangat Setuju & 4 \\
Setuju & 3 \\
Kurang Setuju & 2 \\
Tidak Setuju & 1 \\
\hline
\end{tabular}

Selanjutnya untuk mengetahui presentase setiap komponen menggunakan formulasi sebagai berikut:

$$
p=\frac{f}{n} x 100 \%
$$

Dimana :

$\mathrm{P}=$ Persentase Skor yng dicari

$\mathrm{f}=$ frekuensi

$\mathrm{n}=$ jumlah responden

Setelah diketahui persentase sebagaimana tiap komponen, hasilnya dikonsultasikan dengan kriteria persentase, sebagai berikut : 
Tabel 3

pemasaran,

Telkom

Kriteria Interpresentasi Skor

\begin{tabular}{|c|c|}
\hline Skor Presentase & Kriteria Interpretasi \\
\hline $0 \%-20 \%$ & Sangat Lemah \\
$21 \%-40 \%$ & Lemah \\
$41 \%-60 \%$ & Cukup \\
$61 \%-80 \%$ & Kuat \\
$81 \%-100 \%$ & Sangat Kuat \\
\hline
\end{tabular}

\section{HASIL PENELITIAN}

Strategi pemasaran dipengaruhi oleh strategi harga, strategi produk, strategi promosi, dan 'strategi distribusi. Strategi pemasaran merupakan proses atau cara dari sebuah perusahaan untuk melaksanakan penjualan jasa atau produk kepada konsumen. Oleh karena itu dalam usaha strategi pemasaran tidak asal melaksanakan saja akan tetapi strategi pemasaran harus dapat menunjang tujuan dari PT.Telkom Pontianak serta meningkatkan strategi pemasaran yang baik. Adapun yang mempengaruhi strategi pemasaran menurut Hartono (2012:89).

\section{Strategi Harga}

Harga juga ikut mempengaruhi tingkat penjualan sebuah produk atau jasa karena perusahaan juga harus memperhatikan harga sesuai dengan lingkungan dan kemampuan konsumen. Artinya setiap perusahaan harus selalu memperhitungkan bagaimana menentukan sebuah harga sesuai dengan perputaran pasar agar perusahaan mendapatkan keuntungan dari setiap penjualan. Berikut ini tanggapan responden mengenai strategi harga yang diberikan perusahaan terhadap strategi pemasaran dalam sebuah perusahaan. dilihat pada tabel dibawah ini.

Tabel 4

Tanggapan Responden Mengenai Strategi Harga Dalam Strategi Pemasaran Untuk Meningkatkan Keunggulan yang Kompetitif pada PT. Telkom

\begin{tabular}{|c|l|c|c|}
\hline No & \multicolumn{1}{|c|}{ Keterangan } & $\begin{array}{c}\text { Jumlah } \\
\text { Responden }\end{array}$ & Persentase \\
\hline 1. & Sangat Setuju & 3 & $16,7 \%$ \\
2. & Setuju & 14 & $77,8 \%$ \\
3. & Tidak Setuju & 1 & $5,6 \%$ \\
4. & Sangat Tidak Setuju & - & - \\
\hline \multicolumn{2}{|c|}{ Jumlah } & 18 & $100 \%$ \\
\hline
\end{tabular}

Sumber : Data Olahan, 2020

Berdasarkan tabel diatas menunjukkan bahwa sebanyak 3 responden atau 16,7\% menyatakan sangat setuju bahwa harga berpengaruh dalam strategi perusahaan yang diberikan sesuai dengan jangkauan bahkan beberapa percaya pelanggan lebih mampu dari harga yang 
perusahaan tetapkan, tetapi lebih banyak juga karyawan yaitu 14 responden atau 66,67\% pemasaran,

Telkom menyatakan setuju dengan alasan rata-rata karena dengan harga yang ditawarkan perusahaan saja masih ada yang komentar dengan harga yang ditetapkan, lalu 1 responden atau 5,6\% menyatakan tidak setuju dengan alasan pasti ada pelanggan yang bisa saja tidak mampu membayar dengan harga yang sudah diberikan oleh perusahaan. Artinya pada strategi harga yang di lakukan oleh karyawan PT. Telkom Pontianak, responden lebih banyak menyatakan setuju bahwa harga menjadi salah satu faktor dan mempengaruhi tingkat strategi pemasaran. Jika dibandingkan dengan penelitian sebelumnya mendapatkan hasil dan pengaruh yang sama bahwa harga mempengaruhi tingkat strategi pemasaran.

\section{Strategi Produk}

Produk juga mempengaruhi minat konsumen dalam mengambil sebuah keputusan mengenai sesuai kebutuhannya, tentunya setiap produk mempunyai keunggulannya masingmasing. Konsumen juga selalu memperhitungkan apakah produk yang digunakan sesuai dengan yang dipasarkan oleh pihak penyedia layanan. Maka dari itu perusahaan atau penyedia layanan jasa harus tahu apa saja keinginan dan kebutuhan konsumen dan harus memahami bagaimana sebuah produk atau jasa yang ditawarkan dapat memberikan keuntungan bagi pihak perusahaan. Berikut tanggapan responden mengenai produk apakah dapat mempengaruhi strategi pemasaran dalam meingkatkan keunggulan pada sebuah perusahaan :

Tabel 5

Tanggapan Responden Mengenai Strategi Produk Dalam Strategi Pemasaran Untuk Meningkatkan Keunggulan yang Kompetitif pada PT. Telkom

\begin{tabular}{|c|l|c|c|}
\hline No & \multicolumn{1}{|c|}{ Keterangan } & Jumlah Responden & Persentase \\
\hline 1. & Sangat Setuju & 5 & $27,8 \%$ \\
2. & Setuju & 12 & $66,7 \%$ \\
3. & Tidak Setuju & 1 & $5,6 \%$ \\
4. & Sangat Tidak Setuju & - & - \\
\hline \multicolumn{2}{|r|}{ Jumlah } & 18 & $100 \%$ \\
\hline
\end{tabular}

Sumber : Data Olahan, 2020

Berdasarkan tabel diatas menunjukkan bahwa sebanyak 5 responden atau 27,8\% menyatakan sangat setuju bahwa produk berpengaruh dalam strategi pemasaran dengan memberikan pilihan produk atau jasa kepada pelanggan sehingga pelanggan dengan mudah memilih produk atau jasa apa yang mereka butuhkan, tetapi lebih banyak juga karyawan yaitu 12 responden atau $66,67 \%$ menyatakan setuju saja dengan alasan rata-rata karena bisa jadi konsumen atau pelanggan sudah mempunyai tujuan produk apa yang diinginkan, lalu 1 responden atau 5,6\% menyatakan tidak setuju dengan alasan konsumen sudah bisa menebak 
karena mereka sudah tidak asing dengan produk atau jasa ini. Melihat tanggapan responden pemasaran,

Telkom mengenai produk yaitu lebih banyak yang menyatakan setuju karena produk juga menjadi salah satu yang mempengaruhi tingkat strategi pemasaran.

\section{Strategi Promosi}

Promosi adalah salah satu strategi yang digunakan seluruh perusahaan dalam menawarkan produk atau jasanya, banyak sekali strategi promosi yang di gunakan, itu semua tergantung dari bagaimana cara karyawan dalam perusahaan tersebut membuat promosi yang menarik kepada pihak konsumen. Strategi promosi perusahaan juga sangat mempengaruhi tingkat penjualan produk atau jasa. Semakin bagus sebuah strategi promosi semakin bagus juga tingkat penjualan dan akan mempengaruhi tingkat keuntungan pada perusahaan tersebut.

Berikut ini tanggapan responden mengenai strategi promosi berpengaruh terhadap strategi pemasaran untuk meningkatkan kenggulan yang kompetitif pada PT. Telkom dilihat pada tabel dibawah ini :

Tabel 6

Tanggapan Responden Mengenai Strategi Promosi dalam Strategi Pemasaran Untuk Meningkatkan Keunggulan yang Kompetitif pada PT. Telkom

\begin{tabular}{|c|l|c|c|}
\hline No & \multicolumn{1}{|c|}{ Keterangan } & Jumlah Responden & Persentase \\
\hline 1. & Sangat Setuju & 2 & $11,1 \%$ \\
2. & Setuju & 13 & $72,2 \%$ \\
3. & Tidak Setuju & 3 & $16,7 \%$ \\
4. & Sangat Tidak Setuju & - & - \\
\hline \multicolumn{2}{|c|}{ Jumlah } & 18 & $100 \%$ \\
\hline
\end{tabular}

Sumber : Data Olahan, 2020

Berdasarkan tabel diatas menunjukkan bahwa sebanyak 2 responden atau $11,1 \%$ menyatakan sangat setuju bahwa promosi berpengaruh dalam strategi pemasaran dengan memberikan promosi yang menarik kepada pelanggan sehingga pelanggan sangat tertarik dengan promosi yang diberikan, tetapi lebih banyak juga karyawan yaitu 13 responden atau $72,2 \%$ menyatakan setuju saja dengan alasan karena bisa jadi konsumen atau pelanggan sudah biasa dengan promosi seperti itu sehingga konsumen tidak akan terlalu tertarik dengan promosi yang sering mereka dapatkan, lalu 3 responden atau 16,7\% menyatakan tidak setuju dengan alasan konsumen sudah tidak asing dengan promosi sebuah produk atau jasa sehingga tidak terlalu berpengaruh.

\section{Strategi Distribusi}

Dalam proses pendistribusian barang dan jasa dari tangan produsen dan konsumen, diperlukan suatu metode atau srategi. Metode itu dinamakan saluran distribusi. Saluran 
distribusi adalah kumpulan perusahaan yang mengambil alih hak atau membantu dalam pemasaran, pengalihan hak atas barang atau jasa tertentu, selama barang atau jasa tersebut berpindah tangan dari produsen ke konsumen. Artinya perusahaan menyiapkan strategi yang baik untuk mencapai keuntungan dari hasil penjualan dan pemasaran sebuah produk atau jasa. Berikut ini tanggapan mengenai perilaku adil pimpinan dapat dilihat pada tabel dibawah ini.

Tabel 7

Tanggapan Responden MengenaiStrategi Distribusi Dalam Strategi Pemasaran Untuk Meningkatkan Keunggulan Yang Kompetitif Pada PT. Telkom

\begin{tabular}{|c|l|c|c|}
\hline No & \multicolumn{1}{|c|}{ Keterangan } & Jumlah Responden & Persentase \\
\hline 1. & Sangat Setuju & 16 & $88,9 \%$ \\
2. & Setuju & 2 & $11,1 \%$ \\
3. & Tidak Setuju & - & - \\
4. & Sangat Tidak Setuju & - & - \\
\hline \multicolumn{2}{|r|}{ Jumlah } & 18 & $100 \%$ \\
\hline
\end{tabular}

Sumber : Data Olahan, 2020

Berdasarkan tabel diatas menunjukkan bahwa sebanyak 16 responden atau 88,9\% menyatakan sangat setuju bahwa distribusi atau penjualan yang mereka berikan sangat berpengaruh untuk strategi pemasaran karena dengan konsumen melihat cara penjualan maka konsumen akan percaya bahwa perusahaan memberikan kemudahan dalam melakukan pembelian dan penjualan dalam produk atau jasa, tetapi banyak juga karyawan yaitu 2 responden atau $11,1 \%$ menyatakan setuju bahwa distribusi mempengaruhi karena alasan bisa jadi konsumen atau pelanggan sudah biasa dengan penjualan dan kemudahan yang mereka dapatkan dari perusahaan yang lainnya. Berdasarakan hasil dari tabel diatas dapat dilihat bahwa distribusi mendapat tanggapan responden dengan setuju menjadi hasil terbanyak yaitu distribusi menjadi salah satu faktor yang mempengaruhi dalam strategi pemasaran.

Kendala-Kendala Yang Dihadapi PT. Telkom Pontianak Dalam Meningkatkan Strategi Pemasaran

Dalam usaha meningkatkan strategi pemasaran pastilah perusahaan mengalami kendala. Adapun Kendala-kendala yang di hadapi PT. Telkom Pontianak Dalam Meningkatkan strategi pemasaran adalah :

\section{Kolaborasi}

Beberapa aspek saluran memerlukan lebih banyak bantuan dari pemasaran, sedangkan aspek yang lainnya mungkin memerlukan bantuan dari penjualan, kolaborasi dari pemasaran dan penjualan inilah yang menjadi kendala dalam strategi pemasaran yang dilakukan oleh pihak PT. Telkom Pontianak. Keseimbangan dalam pemasaran dan penjualan yang kadang menjadi 
kendala karena banyaknya kegiatan yang dilakukan oleh usaha dalam pasar yang sama.

Ditambah terkadang hasil dari penjualan yang di dapat tak sesuai dengan besarnya pemasaran.

2. Pencapaian Target

Kesulitan bagi karyawan dan pihak PT. Telkom adalah mengenai target yang akan dicapai dalam setiap pemasaran dan penjualan yang dilakukan, melihat beberapa perusahaan yang sama menjadi kendala bagi PT. Telkom dalam strategi pemasarannya. Kendala dalam strategi ini adalah perusahaan harus mencapai target penjualan dengan merencanakan dan mengatur strategi pemasaran dengan baik agar dapat mencapai target yang diinginkan.

3. Kondisi dan Lingkungan

Kondisi dan lingkungan yang menjadi kendala dalam strategi pemasaran karena pihak perusahaan seringkali mendapatkan pasar yang berubah-ubah dan lingkungan yang terkadang tidak mendukung untuk melakukan sebuah pemasaran, selain dari perusahaan lain yang menjadi pesaing, lingkungan yang tidak sehat seperti sekarang ini menjadi kendala dalam aspek pemasaran pada karyawan dan pihak PT. Telkom Pontianak.

Upaya Apa Saja Yang Dilakukan Oleh PT. Telkom Pontianak Dalam Menghadapi Kendala Pemasaran.

1. Mengenali Pelanggan

Melakukan identifikasi terhadap target pasar dengan menawarkan produk atau jasa kepada konsumen yang siap menerima tawaran mengenai produk atau jasa.

\section{Melakukan Promosi}

Perusahaan melakukan pengenalan produk atau promosi kepada konsumen dengan cara yang kreatif. Dengan cara karyawan membawa brosur dan pamflet yang berisi produk atau jasa perusahaan untuk dibagikan kepada orang yang dituju atau disebarkan ditempat umum. Menghubungi pelanggan ataupun konsumen yang menjadi tujuan pemasaran mengenai produk atau jasa yang baru dikeluarkan dan promo yang sedang berjalan.

3. Memilih lokasi Strategis

Pemilihan lokasi yang perusahaan tentukan kepada karyawannya dalam melakukan pemasaran harus diperhatikan, lokasi yang strategis dan tepat agar mudah di jangkau oleh pelanggan.

\section{DAFTAR PUSTAKA}

Harper W, 2000. Manajemen Pemasaran. Jakarta : Erlangga.

Kotler, Philip. 2002. Manajemen Pemasaran, jilid 1 dan 2. Jakarta : PT. Indeks Kelompok Grammedia. 
2008. Manajemen Pemasaran, edisi 12 Jilid 2. Jakarta : Indeks.

Kotler, P, \& Amstrong. 2012. Prinsip-prinsip Pemasaran, edisi 13 Jilid 1. Jakarta : Erlangga.

Isnaini, Arif, 2005. Model dan Strategi Pemasaran. Makasar : Ntp Press.

Nawawi, Hadari. 2005. Penelitian Terapan. Yogyakarta : Gajah Mada University.

Ridwan. 2004. Metode Penelitian Survei. Jakarta : Pustaka LP3ES.

Suharsimi, Arikunto, 2014. Prosedur Penelitian Pendekatan Praktik. Jakarta : Rineka Cipta.

Sugiyono. 2011. Metodologi Penelitian Pendidikan Kuantitatif dan Kualitatif, dan $R \& D$. Bandung : Alfabeta.

2014. Metodologi Penelitian Pendidikan Kuantitatif dan Kualitatif, dan $R \& D$. Bandung : Alfabeta

Swastha, Basu. 2008. Manaemen Pemasaran Modern, edisi 2. Yogyakarta : Penerbit Liberty Yogyakarta.

2009. Manajemen penjualan. Yogyakarta : BPFE

Tjiptono, Fandy, 2014. Pemasaran Jasa-prinsip, Penerapan, dan Penelitian. Yogyakarta : Andi Offset.

Wirartha, I Made. 2006. Metode Penelitian Sosial ekonomi. Yogyakarta: Andi Offset.

William J. Stanton. Dasar-dasar Pemasaran edisi ke 7. Jakarta : Erlangga. 